\title{
PENGEMBANGAN SISTEM INFORMASI PERPUSTAKAAN UMUM BERBASIS WEB MENGGUNAKAN INLISLITE 3.0 DI KAB. ENREKANG
}

\author{
Andi Muh. Lukman \\ Lulu2k7@gmail.com \\ Fakultas Teknik UPRI
}

\begin{abstract}
Abstrak
Perpustakaan umum Enrekang merupakan tempat yang didirikan untuk memenuhi kebutuhan informasi dalam bentuk media cetak yang bisa diakses oleh semua orang.Pengembangan sistem dilakukan karena sistem yang sebelumnya belum dapat memberikan informasi buku yang ada di perpustakaan umum Enrekang terutama bagi yang tempat tinggalnya jauh dari perpustakaan. Penelitian ini bertujuan untuk mengembangkan sistem informasi yang ada di perpustakaan umum Enrekang sehingga dapat diperoleh manfaat: (1) memudahkan mengakses informasi mengenai buku yang ada di perpustakaan umum Enrekang. (2) dapat melakukan pencarian dan booking buku kapan pun dan dimana pun di tempat yang terjangkau internet.

Pada penelitian ini, pengembangan sistem yang digunakan yaitu UML (Unified Modeling Language).Sedangkan pembuatan perangkat lunak dalam skripsi ini, penulis menggunakan perangkat lunak PHP, HTML,CSS, Java script dan untuk database menggunakan MySql. Untuk mengatasi masalah tersebut pada perpustakaan umum Enrekang, selayaknya di rancang sistem informasi perpustakaan yang berbasis web yang memberi kemudahan bagi pengguna untuk mendapatkan layanan yang diinginkan.Kualitas layanan perpustakaan sangat ditentukan oleh prasarana dan sarana yang mendukung pelayanan tersebut.Sistem informasi perpustakaan dapat membantu pengguna perpustakaan untuk mencari dan menemukan referensi maupun informasi yang cepat, tepat dan akurat.
\end{abstract}

Kata Kunci: Sistem informasi, Perpustakaan, Kualitas layanan pemustaka.

\section{Pendahuluan}

Perpustakaan merupakan suatu satuan kerja organisasi, badan atau lembaga yang bertujuan untuk memberikan pelayanan kepada pemustaka, dan meningkatkan kegemaran membaca.Satuan unit kerja tersebut dapat berdiri sendiri, tetapi dapat juga merupakan bagian dari organisasi diatasnya yang lebih besar.Perpustakaan yang berdiri sendiri seperti perpustakaan umum, Unit Pelaksanaan Teknis pada perpustakaan universitas, dan perpustakaan nasional. Sedangkan perpustakaan yang merupakan bagian dari suatu organisasi yang lebih besar seperti perpustakaan khusus atau kedinasan, dan perpustakaan sekolah.[1]

Di perpustakaan umum Enrekang setiap tahunnya mengalami pertambahan koleksi buku dan sampai sekarang (2017) jumlah buku yang ada di perpustakaan sudah mencapai 35.000 lebih. Untuk anggota perpustakaan total jumlah yang terdaftar adalah lebih dari 2100 anggota dengan berbagai profesi seperti mahasiswa, PNS, pelajar dan umum.

Perpustakaan umum Enrekang saat ini masih terdapat kekurangan mengenai informasiinformasi yang terdapat di pepustakaan umum Enrekang. Tidak adanya sistem yang dapat mempermudah masyarakat untuk mencari informasi membuat masyarakat Enrekang kesulitan dalam pencarian buku dan melihat koleksi buku yang ada di perpustakaan, khususnya bagi yang tempat tinggalnya jauh dari perpustakaan, selain itu tidak ada informasi peminjaman buku dan belum dapat melakukan booking. Anggota perpustakaan yang ingin melakukan peminjaman buku harus datang langsung ke perpustakaan untuk mencari dan melihat informasi buku.

Penggunaan sistem informasi perpustakaan dapat membantu dalam meningkatkan efektivitas kinerja dan efisiensi waktu serta biaya yang timbul dari kegiatan perpustakaan. Selain itu juga dapat membantu dalam proses pemeliharaan data perpustakaan. Berdasarkan latar belakang sebelumnya maka dibuatlah "Sistem Informasi Perpustakaan Umum Berbasis Web menggunakan Inlislite 3.0 di Kab.Enrekang" dimana dengan adanya sistem ini dapat mempermudah masyarakat Enrekang untuk medapatkan informasi tanpa harus ke perpustakaan.Anggota perpustakaan dapat melakukan pencarian dan booking buku kapanpun dan dimanapun di tempat yang terjangkau jaringan internet.Sistem yang dibangun menggunakan pemrograman HTML, PHP (Hypertext Prepocessor)dan database MySQL.[2] 


\section{ILKOM Jurnal IImiah Volume 9 Nomor 1 April 2017}

Pada penelitian ini, yang menjadi rumusan masalah adalah bagaimana menganalisis dan merancang Sistem Informasi Perpustakaan Umum Berbasis Web menggunakan Inlislite 3.0 di Kab.Enrekang serta bagaimana mengimplementasikan Sistem Informasi Perpustakaan Umum Berbasis Web menggunakan Inlislite 3.0 di Kab.Enrekang. Untuk mempertajam sasaran dan membatasi ruang lingkup, berikut ini adalah beberapa batasan masalah, yaitu kriteria-kriteria yang dinilai adalah Data anggota, Data buku, Peminjaman,Pengembalian, Denda. Penelitian ini bertujuan untuk menganalisis dan merancang sistem informasi perpustakaan umum berbasis web menggunakan Inlislite 3.0 di Kab.Enrekang serta untuk mengimplementasikan Sistem Informasi Perpustakaan Umum Berbasis Web menggunakan Inlislite 3.0 di Kab.Enrekang.

Manfaat yang dapat dihasilkan dari perancangan sistem ini adalah memberikan kontribusi terhadap ilmu pengetahuan pada bidang sistem informasi khususnya dalam pengembangan sistem informasi perpustakaan dan perkembangan teknologi yang mampu diadopsi untuk meningkatkan pelayanan kepada pengguna. Mempermudah masyarakat mencari, booking dan melihat koleksi buku yang ada di perpustakaan umum Enrekang. Membantu mengurangi pekerjaan petugas perpustakaan.

\section{Metode}

\subsection{Perpustakaan}

Perpustakaan adalah kumpulan atu bangunan fisik sebagai tempat buku dikumpul dan disusun menurut sistem tertentu atau keperluan tertentu[3]. Maksud pendirian perpustakaan adalah menyediakan sarana atau tempat untuk menghimpun suatau sumber informasi untuk dikoleksi terusmenerus, diolah dan diproses.Sebagai sarana dan wahana untuk melestarikan hasil budaya manusia (ilmu pengetahuan, teknologi, dan budaya) melalui aktivitas pemeliharaan dan pengawetan koleksi. Sebagai agen perubahan (agent of changes) dan agen kebudayaan serta pusat informasi dan sumber belajar mengenai masa lalu, sekarang dan masa akan datang, selain itu juga dapat menjadi pusat penelitian, rekreasi dan aktivitas ilmiah lainnya. Tujuan pendirian perpustakaan yaitu untuk menciptakan masyarakat terpelajar dan terdidik, terbiasa membaca, budaya tinggi serta mendorong terciptanya pendidikan sepanjang hayat.[4]

\subsection{Konsep Dasar Sistem}

Sistem merupakan bagian yang saling berkaitan erat dan membentuk suatu kesatuan yang saling berinteraksi antara bagian satu dengan bagian lainnya untuk mencapai suatu tujuan, artinya apabila salah satu bagian dari sistem tidak ada maka sistem tersebut tidak akan berfungsi sebagaimana mestinya.[5]. Suatu sistem didalam suatu organisasi yang mempertemukan kebutuhan pengolahan transaksi, mendukung operasi, bersifat manajerial, dan kegiatan strategi dari suatu organisasi dan menyediakan pihak luar tertentu dengan laporan-laporan yang diperlukan.[6]

\subsection{UML (Unified Modeling Language)}

UML singkatan dari Unified Modeling Language yang berarti bahasa pemodelan standar.Ketika kita membuat model menggunakan konsep UML ada aturan-aturan yang harus diikuti.Bagaimana elemen pada model-model yang kita buat berhubungan satu dengan yang lainnya harus mengikuti standar yang ada. UML bukan hanya sekedar diagram tetapi juga menceritakan konteksnya.[7] UML diaplikasikan untuk maksud tertentu biasanya antara lain untuk:

a. Merancang Perangkat Lunak

b. Sarana Komunikasi antara perangkat lunak dengan proses bisnis

c. Menjabarkan sistem secara rinci untuk analisa dan mencari apa yang diperlukan sistem

d. Mendokumentasi sistem yang ada, proses-proses dan organisasinya.

UML (Unified Modeling Language) adalah 'bahasa' pemodelan untuk sistem atau perangkat lunak yang berparadigma 'berorientasi objek". Pemodelan (modeling) sesungguhnya digunakan untuk penyederhanaan permasalahan-permasalahan yang kompleks sedemikian rupa sehingga lebih mudah dipelajari dan dipahami [8]. Class diagram merupakan himpunan dari objek-objek yang sejenis. Sebuah objek memiliki keadaan sesaat (state) dan perilaku (behavior). State sebuah objek adalah kondisi objek tersebut yang dinyatakan dalam attribute/properties. Sedangkan perilaku suatu objek mendefinisikan bagaimana sebuah objek bertindak/beraksi dan memberikan reaksi. [9].

World Wide Web atau WWW juga dikenal dengan WEB adalah salah satu layanan yang dapat diakses oleh pemakai computer yang terhubung ke internet dengan fasilitas hypertext untuk menampilkan data berbentuk text, gambar, suara, animasi dan data multimedia lainnya. dengan menggunakan teknologi hypertext, pemakai dituntun menemukan informasi dengan mengikuti link yang disediakan dalam dokumen web yang ditampilkan dalam web browser. Sehingga dapat 
ILKOM Jurnal Ilmiah Volume 9 Nomor 1 April 2017

disimpulkan bahwa kelebihan dari aplikasi web adalah dapat diakses kapan pun dan dimana pun selama ada jaringan internet. [10]

\subsection{MySQL}

MySQL adalah perangkat lunak yang tergolong sebagai DataBase Managament System (DBMS). Perangkat lunak ini bermanfaat untuk mengelola data dengan cara yang sangat fleksibel dan cepat. Berikut adalah sejumlah aktivitas yang tekait dengan data yang didukung oleh MySQL. [11]

1. Menyimpan data ke dalam tabel;

2. Menghapus data dalam tabel;

3. Mengubah data dalam tabel;

4. Mengambil data yang tersimpan dalam tabel;

5. Memungkinkan untuk memilih data tertentu yang diambil;

6. Memungkinkan untuk melakukan pengaturan hak akses terhadap data.

\subsection{Metode Pengujian Black Box}

Behavioral atau black boxtests merupakan pengujian mengenai apa yang dilakukan oleh sistem, terutama perilakunya (behavior) dan masalah-masalah bisnis. Black box test dilakukan untuk mengidentifikasi bug yag terdapat pada hasil-hasil, pemrosesan dan perilaku dari sistem Black box test biasanya dilakukan oleh tester.[12]

\subsection{Penggambaran Sistem}

a. Rancangan Sistem yang Sedang Berjalan

Pada sistem yang sedang berjalan terdapat dua aktor yaitu anggota dan staf pengelola.Yang pertama dilakukan anggota adalah mendaftar menjadi anggota, mencari buku, menyewa buku, mengembalikan buku kemudian membayar denda.Sedangkan staf pengelola bertugas untuk mengolah data anggota, mengolah data buku dan membuat laporan.

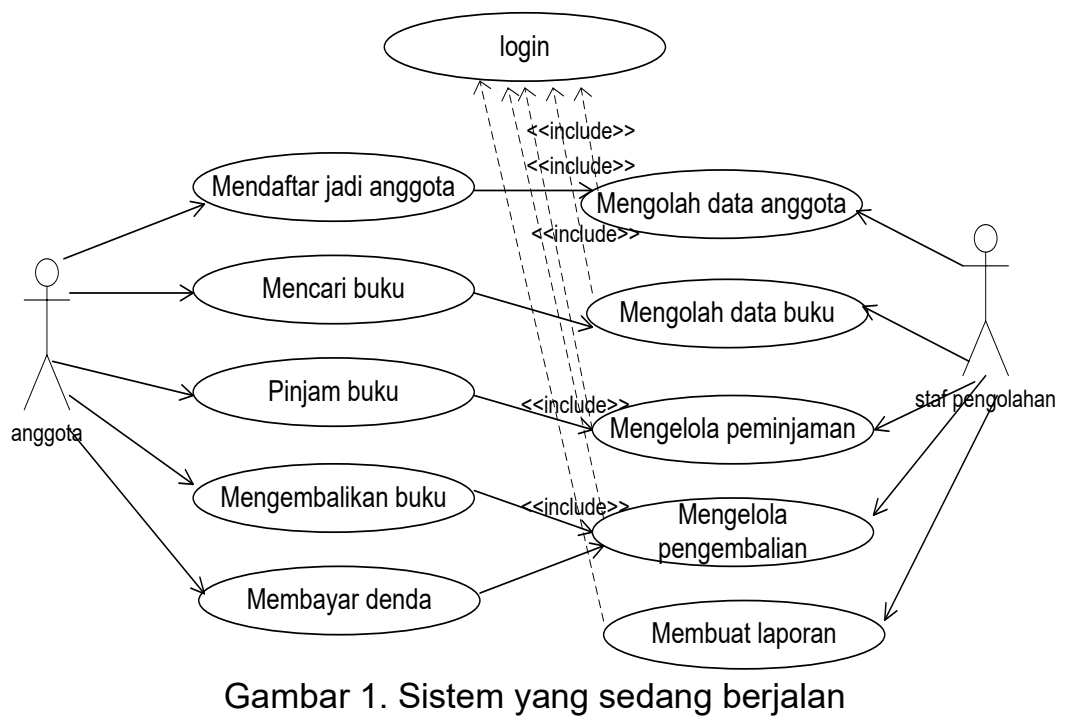

Adapun kekurangan dari sistem yang sekarang yaitu tidak adanya sistem yang dapat mempermudah masyarakat untuk mencari informasi membuat masyarakat Enrekang kesulitan dalam pencarian buku dan melihat koleksi buku yang ada di perpustakaan, khususnya bagi yang bertempat tinggal jauh dari perpustakaan.Tidak hanya itu tidak adaya informasi jatuh tempo peminjaman buku.

b. Rancangan Sistem yang Diusulkan

Pada sistem yang diusulkan kami merancang suatu sistem yang dapat mempermudah masyarakat Enrekang mengakses informasi di perpustakaan umum Enrekang.

Berdasarkan pada gambar 2 di bawah pada rancangan sistem yang diusulkan, yang pertama dilakukan anggota yaitu:

1. Mendaftar sebagai anggota

2. Melihat informasi buku

3. Mencari koleksi buku

4. Melakukan booking 
ILKOM Jurnal Ilmiah Volume 9 Nomor 1 April 2017
5. Pinjam buku
6. Mengembalikan buku
7. membayar denda

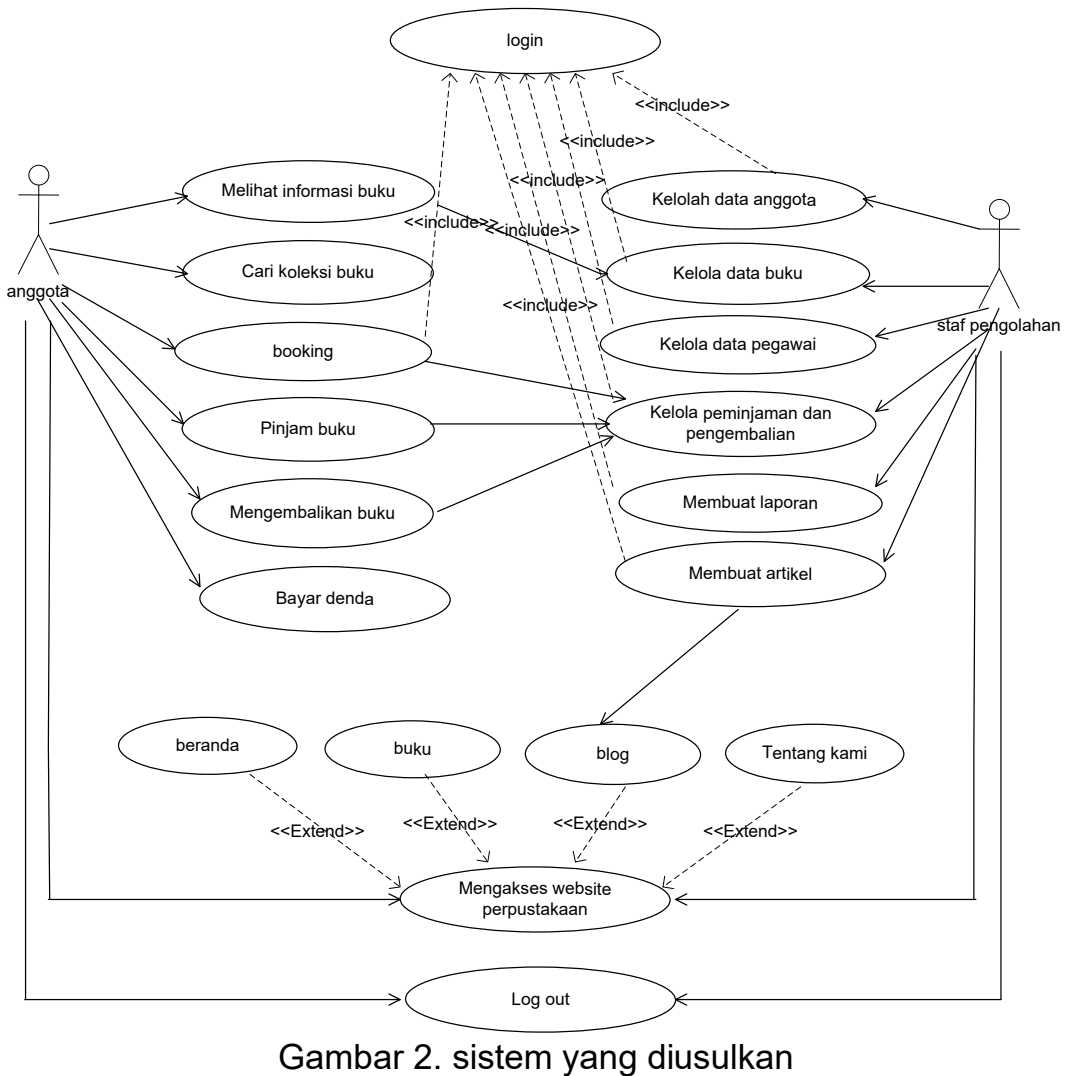

Sedangkan untuk staf pengolahan/admin adapun langkah yang harus dilakukan adalah:

1. Login untuk dapat mengelola data yaitu data anggota, data buku, data pegawai, dan peminjaman membuat artikel.

2. Kelola data anggota.

3. Kelola data buku.

4. Kelola data pegaai.

5. Kelola data peminjaman.

6. Kelola artikel

Dilihat dari penggambaran sistem, terlihat jelas perbedaan sistem yang sedang berjalan dengan sistem yang diusulkan.Pada sistem yang sedang berjalan untuk mengetahui informasi buku kita masih harus datang langsung ke perpustakaan.Sedangkan pada sistem yang diusulkan memiliki kelebihan dibanding sistem yang sedang berjalan.Kelebihan yang dimiliki yaitu orang dapat mencari informasi buku kapan pun dan dimanapun di tempat yang terjangkau jaringan internet.Selain itu bagi anggota perpustakaan juga dapat melakukan booking dan melihat stok buku yang ada.

c. Analisis Kebutuhan

1. Kebutuhan pengguna

a) Anggota sebagai seseorang yang akan melihat informasi buku, booking dan meminjam buku.

b) Staf pengolahan/admin sebagai seseorang yang mengatur pengolahan data buku, peminjaman, pengembalian, dan bayardenda.

2. Kebutuhan perangkat keras (hadware)

Adapun spesifikasi hardware yang dibutuhkan oleh sistem ini adalah sebagai berikut:

a. Processor intel centrino

b. Hardisk minimal $30 \mathrm{MB}$

c. Memory

d. Monitor 
ILKOM Jurnal IImiah Volume 9 Nomor 1 April 2017
e. Keyboard
f. Print
g. Mouse

3. Kebutuhan Perangkat Lunak

Untuk menjalankan sistem informasi Pengelolaan ini dibutuhkan perangkat lunak (Software).adapunsoftware yang dibutuhkan yaitu sistem operasi Windows $7 / 8$, sedangkan pembuatan sistem dibutuhkan software sebagai berikut:
1. $P H P$
: sebagai bahasa pemrograman yang dipakai
2. $X A M P P$
: menjalankan MySQL
3. $M y S Q L$
: database yang digunakan.
4. Google chroms : web browser yang menjalankan program aplikasi.
5. Apache2triad : sebagai server aplikasi yang akan menjalankan web browser.

d. Pemodelan sistem (Unified Modeling Language (UML))

Use case adalah gambaran fungsionalitas dari suatu sistem,sehingga pengguna sistem paham dan mengerti mengenai kegunaan sistem yang akan dibangun. Use case digunakan untuk memodelkan dan menyatakan unit fungsi/layanan yang disediakan oleh sistem ke pemakai. Gambaran use case secara jelas dapat kita lihat pada gambar 3 di bawah ini.

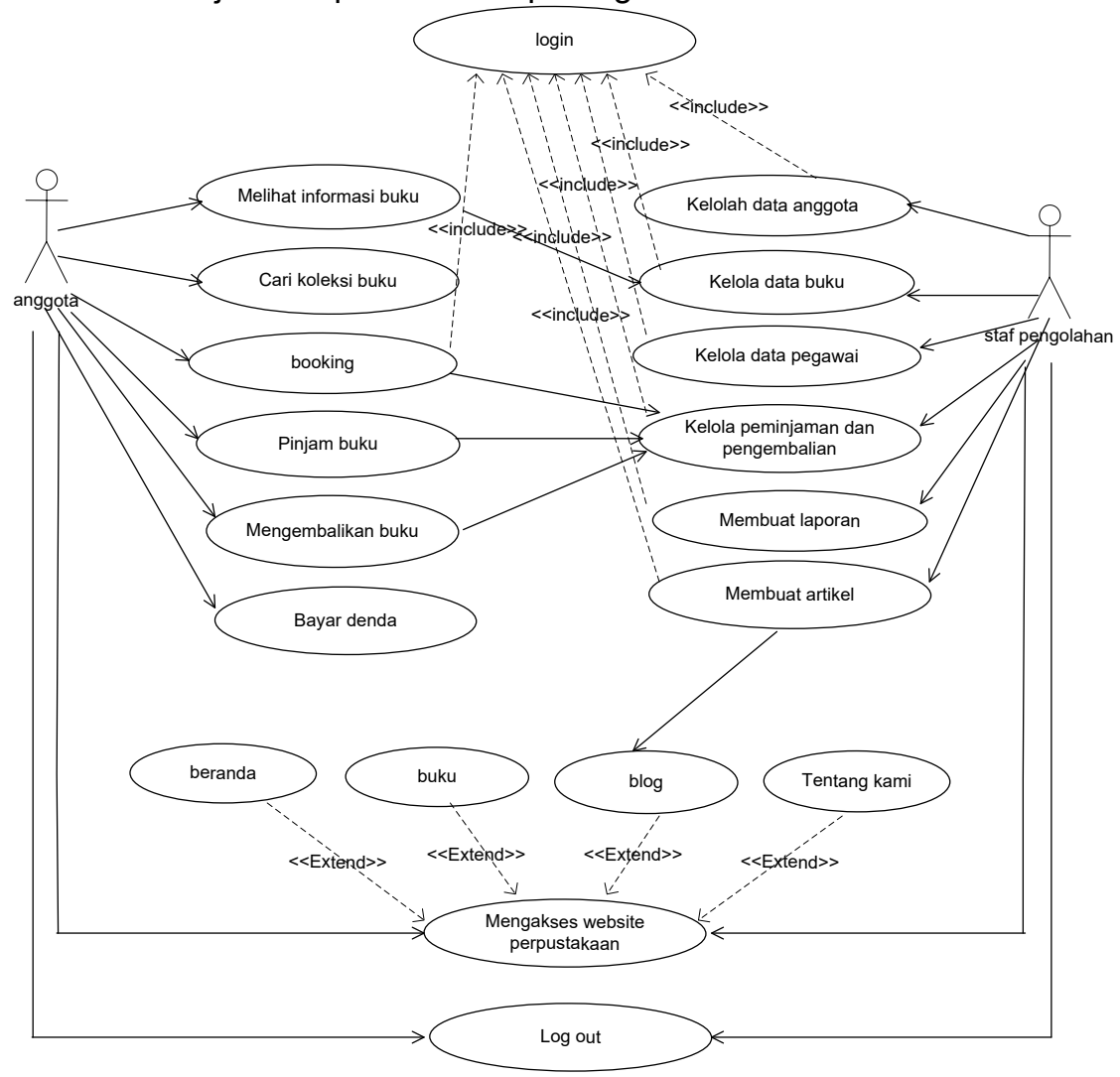

Gambar 3. Use case

Penjelasan use case:

Pada use case terdapat dua aktor yaitu anggota dan staf pengolahan. Yang pertama dilakukan adalah anggota mendaftar sebagai anggota perpustakan agar dapat meminjam buku.kemudian staf pengolahan login terlebih dahulu kemudian mengelola data anggota, data buku dan data pegawai. Setelah itu anggota dapat melihat informasi buku, selanjutnya anggota mencari koleksi buku, jika sudah mendapatkan buku yang di cari anggota dapat melakukan booking. Kemudian staf pengolahan mengkonfirmasi booking. Anggota perpustakaan meminjam buku yang telah dibooking kemudian staf pengelola mengkonfirmasi peminjaman. Selanjutnya anggota mengembalikan buku dan staf pengolahan mengkonfirmasi pengembalian buku.anggota membayar denda jika buku yang dipinjam melewati batas pengembalian. Anggota perpustakaan dan staf pengolahan sama-sama dapat mengakses website perpustakaan.Ada empat halaman yang dapat diakses yaitu halaman beranda, buku, blog dan tentang kami. Anggota perpustakaan dan staf pengolahan sama-sama melakukan log out. 


\section{ILKOM Jurnal Ilmiah Volume 9 Nomor 1 April 2017}

Pada use terdapat dependensi yaitu include dan extend. Include merupakan penghubung antara dua use case dimana yang satu memanggil yang lain. Pada yang lain yaitu anggota melakukan pendaftaran untuk menjadi anggota perpustakaan kemudian staf pengolahan terlebih dahulu harus melakukan login untuk dapat mengelola data anggota tersebut. Sedangkan extend merupakan turunan dari use case dasar, memperluas use case tergantung use case dasar. Beranda, buku, bloog, dan tentang kami merupakan turunan dari use case website perpustakaan. Keempat halaman tersebut dapat diakses tanpa melakukan login terlebuh dahulu.

\subsection{Perancangan Antar Muka}

1. Perancangan Output

a. Perancangan output Daftar Buku, dimana terdapat menu judul buku, kode buku, pengarang, penerbit dan barcode.

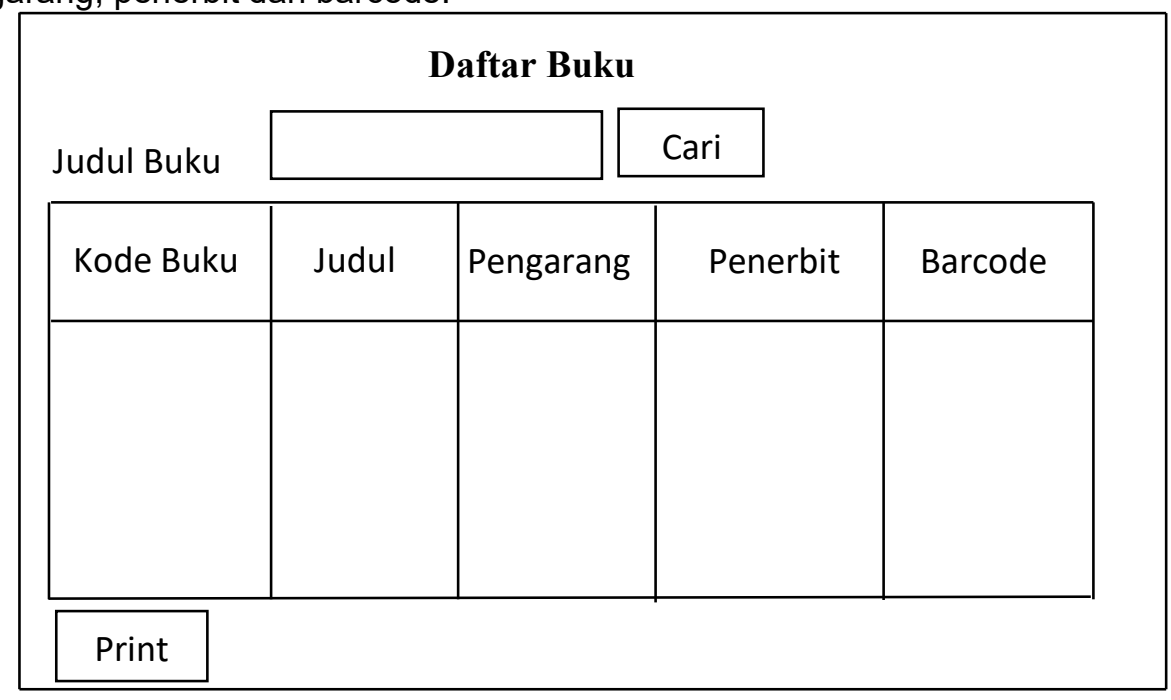

Gambar 4. Rancangan Output Daftar Buku

b. Perancangan output Daftar Judul Buku, pada tampilan ini terdapat menu judul buku, pengarang, penerbit, tahun, halaman dan jumlah eksamplar.

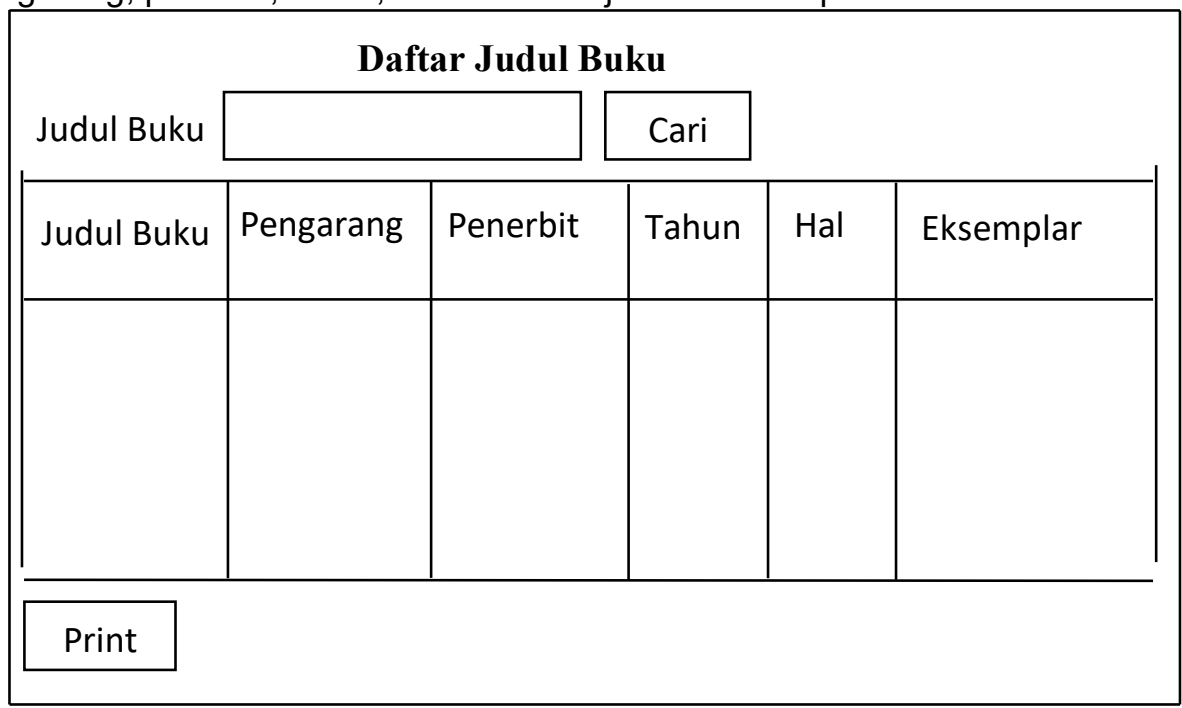

Gambar 5. Rancangan Output Daftar Judul Buku

\section{Hasil dan Pembahasan}

\subsection{Implementasi}

a. Tampilan Login

Pada tampilan di bawah ini merupakan tampilan login bagi pegawai atau staf perpustakaan, kemudian mengelola data anggota, data buku dan data pegawai. Pada tampilan ini staf diminta menginput nama pengguna dan kata kunci. Jika data yang diinput benar, maka pengguna dapat mengakses sistem. 


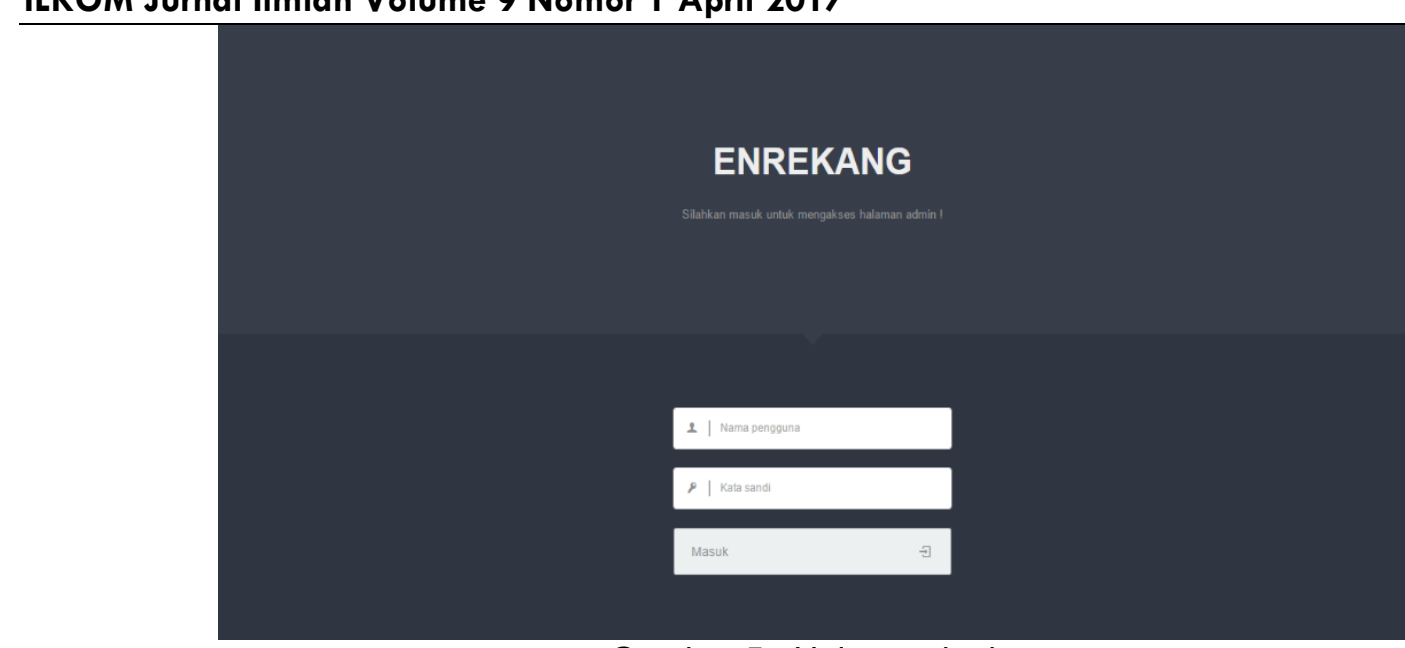

Gambar 5. Halaman login

b. Tampilan Halaman utama atau beranda

Pada tampilan ini pengguna dapat melihat menu-menu yang ada pada sistem informasi perpustakaan

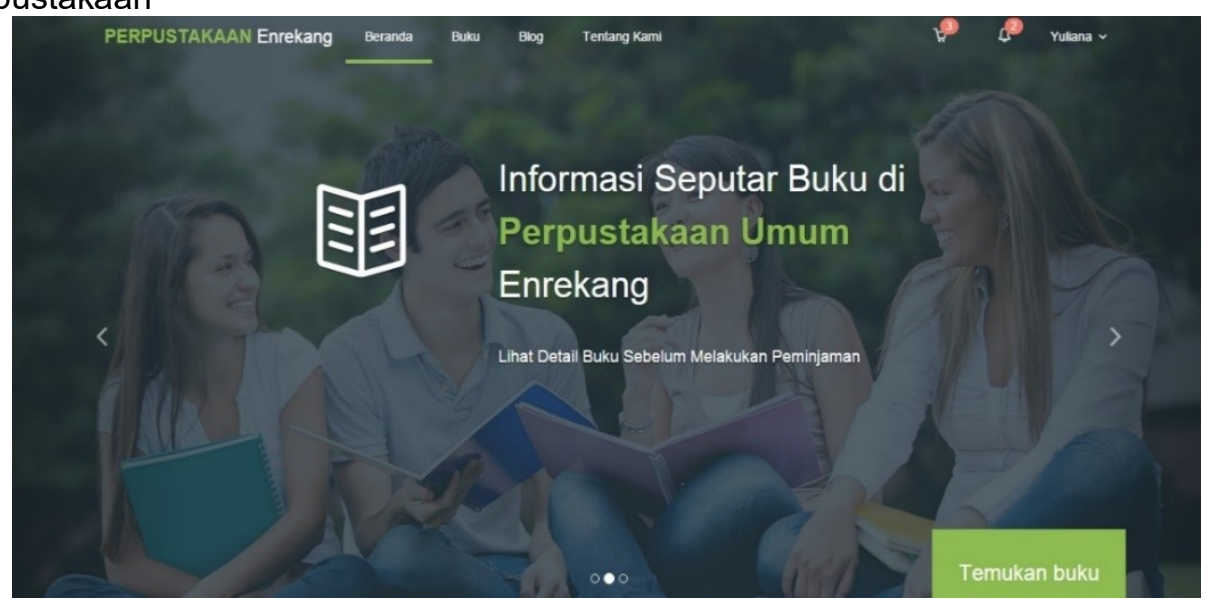

Gambar 6. Halaman beranda

Pengujian terhadap sistem telah dilakukan dengan metode Behavioral atau black boxtests yang merupakan pengujian mengenai apa yang dilakukan oleh sistem, terutama perilakunya (behavior) dan masalah-masalah bisnis. Black box test dilakukan untuk mengidentifikasi bug yang terdapat pada hasil-hasil, pemrosesan dan perilaku dari sistem Black box test biasanya dilakukan oleh tester. Hasil yang diperoleh yaitu sistem yang telah dirancang sudah bebas dari kesalahan baik pada proses maupun hasilnya sehingga sistem siap untuk diimplementasikan.

\section{Kesimpulan dan Saran}

\subsection{Kesimpulan}

Setelah melakukan serangkaian pengujian pada aplikasi sistem informasi perpustakaan umum Enrekang yang telah dikembangkan, penulis akhirnya dapat menarik kesimpulan sebagai berikut:

1. Dibandingkan dengan sistem sebelumnya, dengan adanya sistem informasi berbasis web yang sekarang ini dapat mempermudah masyarakat Enrekang mengetahui informasi buku yang ada di perpustakaan umum Enrekang.

2. Anggota perpustakaan dapat melakukan pemesanan buku kapan pun dan dimana pun di tempat yang terjangkau jaringan internet.

3. Dapat menghemat waktu untuk pencarian dan pencatatan data.

4. Dapat menyajikan informasi secara efektif dan efisien.

\subsection{Saran}

Adapun saran-saran yang diberikan penulis untuk pengembangan aplikasi sistem perpustakaan umum berbasis web menggunakan Inlislite 3.0 di Kab. Enrekang ini yaitu: 


\section{ILKOM Jurnal Ilmiah Volume 9 Nomor 1 April 2017}

1. Diharapkan dengan adanya aplikasi sistem informasi perpustakaan berbasis web menggunakan Inlislite 3.0 ini dapat dimanfaatkan oleh pemustaka perpustakaan semaksimal mungkin.

2. Aplikasi sistem informasi perpustakaan berbasis web menggunakan Inlislite 3.0 ini diharapkan terus dikembangkan sesuai kebutuhan yang ada.

3. Diperlukan peran aktif petugas dan anggota perpustakaan dalam pengelolaan dan pemanfaatan aplikasi sistem informasi perpustakaan berbasis web menggunakan Inlislite 3.0 di Kab. Enrekang.

\section{Daftar Pustaka}

[1] Ibrahim, Andi. 2015.Pengantar IImu Perpustakaan Dan Kearsipan. Gunadarma IImu. Jakarta.

[2] Supriyanto A. 2011. WEB dengan HTML dan XM., Graha IImu. Yogyakarta:

[3] Lasa. 2011. Manajemen Perpustakaan Sekolah Edisi Revisi. Pinus. Yogyakarta.

[4] Sutarno NS. 2010. Perpustakaan dan Masyarakat. Sagung SetoWidodo. Jakarta.

[5] Jogiyanto,HM. 2013. Analisis dan Desain Sistem Informasi. AndiOffset. Yogyakarta.

[6] Al-Bahra. 2012. Analisis dan Desain Sistem Informasi. Graha Ilmu. Yogyakarta.

[7] Prabowo Pudjo. Herlawati.2013. Menggunakan UML. Informatika. Bandung.

[8] Nugroho, Adi. 2010. Analisis Perancangan Sistem Informasi dengan Metodologi Berorientasi Object.Informatika. Bandung

[9] Munawar. 2011. Pemodelan Visual Menggunakan UML. Graha Ilmu. Yogyakarta.

[10] Sidik, B., Husni, I.P. 2012. Pemrograman Web dengan HTML. Informatika. Bandung

[11] Abdul Kadir. 2010. Manajemen Data Base. Andi Offset. Yogyakarta.

[12] Roger S. Pressman. 2013. Rekayasa Perangkat Lunak Pendekatan Prakti Buku 1 Edisi Revisi. Andi Offset. Yogyakarta. 